BioLink

Jurnal Biologi Lingkungan, Industri, Kesehatan

Available online http://ojs.uma.ac.id/index.php/biolink

\title{
THE DNA SEQUENCE ENCODING GLYCERALDEHYDE 3- PHOSPHATE DEHYDROGENASE (GAPC) ENZYME ON TUNTUN ANGIN PLANT (ELAEOCARPUS FLORIBUNDUS BI)
}

\author{
Dewi Indriyani Roslim*, Hestia Hairima, Herman, and Wahyu Lestari \\ Biology Departement, FMIPA, Universitas Riau, Indonesia \\ Received : 09-01-2020; Reviewed : 10-01-2020: Accepted : 17-02-2020 \\ *Corresponding author: E-mail : dewiindriyaniroslim@gmail.com
}

\begin{abstract}
Glyceraldehyde 3-phosphate dehydrogenase (GapC) is an enzyme involved in glycolysis. The expression of this gene tends to abundant in eukaryotic cells, so this gene is frequently used as an internal control in gene expression analysis. This research aims to isolate the DNA sequence of the GapC gene from tuntun angin (Elaeocarpus floribundus BI). Methods included a collection of the leaves from Kajuik Lake, Riau Province then the DNA extraction, electrophoresis, amplification of partial DNA sequence of GapC gene, cloning and sequencing. The DNA sequence was analyzed using the BLASTn program and MEGA6 software. The GapC sequence obtained in this study was 933 bp in size, consisting of four introns and five exons, and encoding 137 deduced amino acids. The BLASTn analysis showed that the sequence has 89.84\%-90.16\% similarity to other species of Cunoniaceae family, such as species from the genus of Spiraeanthemum and Codia. The parsial sequence of E. floribundus GapC gene was more resemble the one of Spiraeanthemum than Codia genus. The GapC sequence obtained in this study was the first reported from the Elaeocarpaceae family. This sequence has the opportunity to serve as an internal control after validation.
\end{abstract}

Keywords: GapC gene, Elaeocarpus floribundus, internal control, Riau.

How to Cite: Roslim, D.I., Hairima, H., Herman, and Lestari, W. (2020). The DNA Sequence Encoding Glyceraldehyde 3-Phosphate Dehydrogenase (GapC) Enzyme on Elaeocarpus Floribundus BI, BioLink: Jurnal Biologi Lingkungan, Industri dan Kesehatan, Vol.7 (1): Hal. 16-22 
Roslim, D.I., Hairima, H., Herman, and Lestari, W. The DNA Sequence Encoding Glyceraldehyde 3-Phosphate Dehydrogenase (GapC) Enzyme on Elaeocarpus Floribundus BI

\section{INTRODUCTION}

The Elaeocarpus floribundus BI plant is a species of the Elaeocarpaceae family that grows in Lake Kajuik, Riau Province (Elvyra \& Yus, 2012; Roslim et al., 2016). This plant has adapted well to the flood exposure ecosystem, that is, this plant can grow well in flooded conditions for months during the rainy season. This shows that this plant is most likely to carry inundation-tolerant genes.

To study the theory that underlies the tolerance of plants to inundation stress, it is necessary to analyze the expression of these genes. For this purpose several reference genes are needed which act as internal controls in gene expression studies (Ezin et al., 2012; Wang et al., 2017). One gene that is often used as internal control in plants is the gene coding for the enzyme glyceraldehyde 3-phosphate dehydrogenase (GapC) (Kozera \& Rapacz, 2013). In wheat plants (Triticum aestivum) 4 groups of gene coding for the enzyme glyceraldehyde

3-phosphate dehydrogenase (GAPDH) were identified, namely GapA / B, GapC, GapCp, and GapN (Zeng et al., 2016).

This gene is involved in glycolysis and is expressed in abundant amounts in plant cells. The universal primer for amplifying this gene has been designed by Strand et al. (1997).

Therefore, this study aims to isolate partial DNA sequences of the GapC gene in E. floribundus plants.

\section{MATERIALS AND METHODS}

The research was conducted from January to April 2019. The research material was in the form of leaves from Elaeocarpus floribundus taken from Kajuik Lake in Riau Province. Molecular analysis was carried out in the Genetics laboratory, Department of Biology, FMIPA, Riau University, Indonesia. The primers used are as follows: GPDX7F: 5'-GAT AGA TTT GGA ATT GTT GAG G-3 'and GPDX9R: 5'AAG CAA TTC CAG CCT TGG-3' (Strand et al., 1997; Wu et al. , 2007).

Total of DNA Isolation. The total DNA molecule from the E. floribundus plant was isolated using the Genomic DNA Mini Kit (Plant, Geneaid GP100). 100 mg of leaves were crushed using mortar and pestle and assisted with liquid nitrogen. The total DNA molecule obtained was then migrated to $1.2 \%$ agarose gel in a $1 \mathrm{X}$ TBE buffer solution to determine the success of DNA isolation.

Polymerase Chain Reaction (PCR), Cloning and Sequencing. The total DNA molecule is then used as a template to amplify the GapC gene using the primer 
pair of GPDX7F / GPDX9R. The annealing temperature used is $52.3^{\circ} \mathrm{C}$. Components and PCR programs follow Roslim et al. (2018). The target gene PCR product is then inserted into a pTA2 vector (Toyobo) and then transformed into the bacterial cell Escherichia coli Zymo $5 \alpha$ (Zymo Research). Transformed colonies were amplified using $\mathrm{T} 3$ and $\mathrm{T} 7$ promoter primers. Plasmids from selected colonies were then isolated using ZR Plasmids MiniPrep (Zymo Research) and sequenced using T3 and T7 promoter primers.

Data Analysis. The DNA sequence data was analyzed by bioinformatics using the BLASTn program. The GapC sequence of 10 accessions that appeared in the BLASTn analysis was downloaded to create a dendrogram using MEGA6 software with Neighbor Joining Tree, Kimura-2-Parameter model and 1000 bootstraps.

\section{RESULTS AND DISCUSSION}

PCR products from the GapC gene in the Elaeocarpus floribundus plant have been obtained with a size of around $1000 \mathrm{bp}$ (Picture 1). These results are not much different from those found in Hibiscus tiliaceus plants. Amplification of the $G a p C$ gene in $H$. tiliaceus plants produced a band of about 950 bp (Wu et al., 2007).

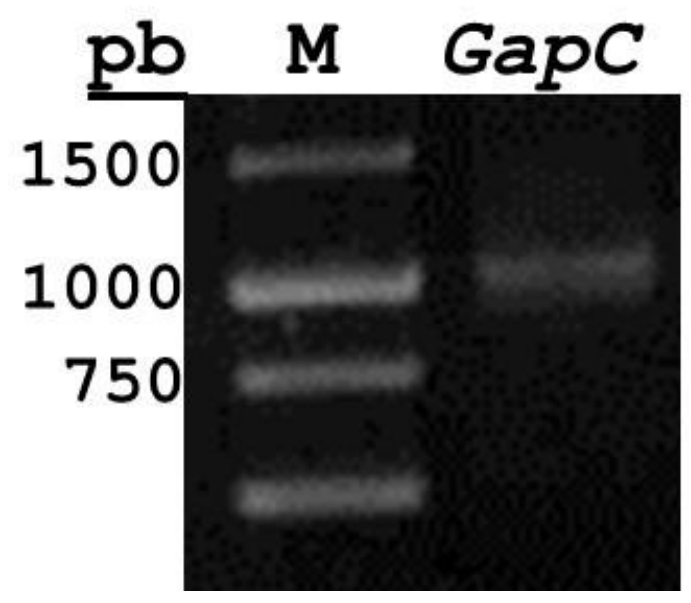

Picture 1. DNA band profile of the Elaeocarpus floribundus GapC gene in 1.2\% agarosa gel. $\mathrm{pb}=$ base pairs; $\mathrm{M}=1 \mathrm{~kb}$ of DNA Ladder (Thermo Scientific); GapC = DNA band from the GapC gene.

The GapC gene PCR product in this study is included in the nucleus with a low copy appeared thin when electrophoresed. The number. Therefore, cloning was carried out on thin GapC gene band obtained in this study shows the amount of amplification products is small. According to Olsen \& Schaal (1999) the plasmid vector so that sequencing could be carried out properly and the DNA sequences obtained were accurate. The and $\mathrm{Wu}$ et al. (2007) the GapC gene in plants sequencing results of the E. floribundus GapC 
Roslim, D.I., Hairima, H., Herman, and Lestari, W. The DNA Sequence Encoding Glyceraldehyde 3-Phosphate Dehydrogenase (GapC) Enzyme on Elaeocarpus Floribundus BI

gene were $933 \mathrm{bp}$. The sequence has been registration number MK942072 (Picture 2). registered in GenBank database with

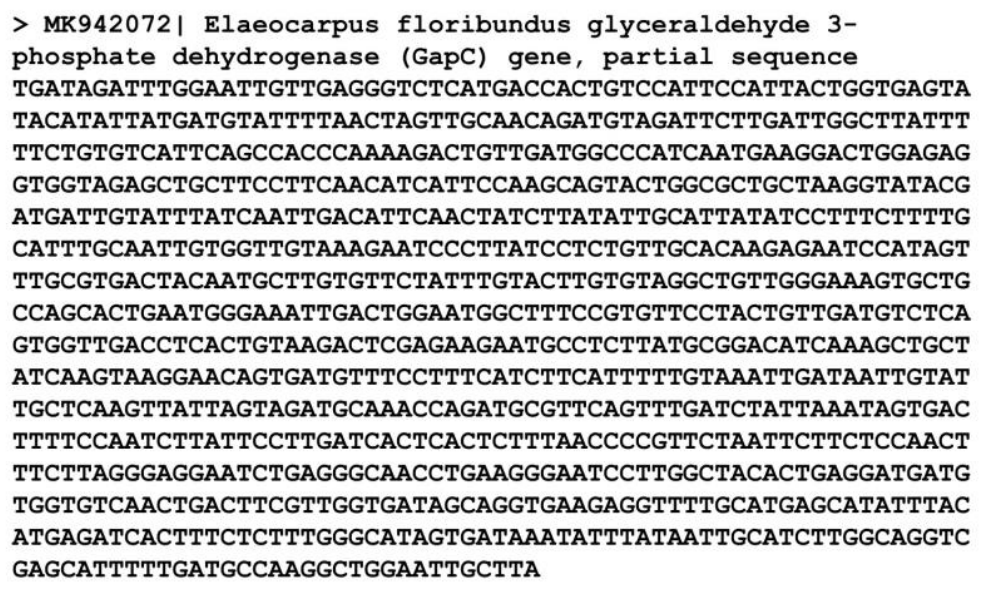

Picture 2. DNA sequence of the GapC gene from Elaeocarpus floribundus.

Using the same primer, Olsen \& Schaal (1999) obtained the GapC gene in cassava (Manihot esculenta) with a size of 962 bp. Wu et al. (2007) have also obtained the GapC gene in H. tiliaceus plants with a size of $935 \mathrm{bp}$.

The E. floribundus GapC gene sequence obtained in this study is predicted to consist of 4 introns and 5 exons. These results are consistent with those obtained in cassava plants (Olsen \& Schaal, 1999). The position of the exons in the E. floribundus GapC gene is in nucleotides 1-53, 136-233, 403-545, 728811, and 898-933. The total exon is estimated to be around $409 \mathrm{bp}$ and encodes 137 amino acid deductions.
The results of the BLASTn GapC E. floribundus sequence show that the $E$. floribundus GapC sequence has a high similarity, which is $89.84 \%-90.16 \%$ with several species from the Cunoniaceae family (Table 1).

The same gene from several different species will have many similarities. High similarity shows that the gene has the same role in cells (Claverie \& Notredame, 2007).

In this study, the E. floribundus GapC gene sequence has a high similarity with several plant species with different families because the GapC gene in all plants plays a role in the process of glycolysis. 
Table 1. BLASTn analysis results on the Elaeocarpus floribundus GapC gene sequence.

\begin{tabular}{lccc}
\multicolumn{1}{c}{ Species } & Query Cover (\%) & Identity (\%) & Family \\
\hline S. densiflorum & 90 & 89.84 & Cunoniaceae \\
C. triverticillata & 85 & 90.16 & Cunoniaceae \\
C. spatulata & 85 & 90.16 & Cunoniaceae \\
C. montana & 85 & 90.16 & Cunoniaceae \\
C. microphylla & 85 & 90.16 & Cunoniaceae \\
C. mackeeana & 85 & 90.16 & Cunoniaceae \\
C. jaffrei & 85 & 90.16 & Cunoniaceae \\
C. incrassata & 85 & 90.16 & Cunoniaceae \\
C. ferruginea & 85 & 90.16 & Cunoniaceae \\
C. belepensis & 85 & 90.16 & Cunoniaceae \\
\hline
\end{tabular}

The dendrogram shows that the $E$. (Figure 3). This result shows that the $E$. floribundus GapC sequence forms a group floribundus GapC sequence has more with Spiraeanthemum densiflorum and is similarities with the $S$. densiflorum GapC separated from species of Codia genus sequence.

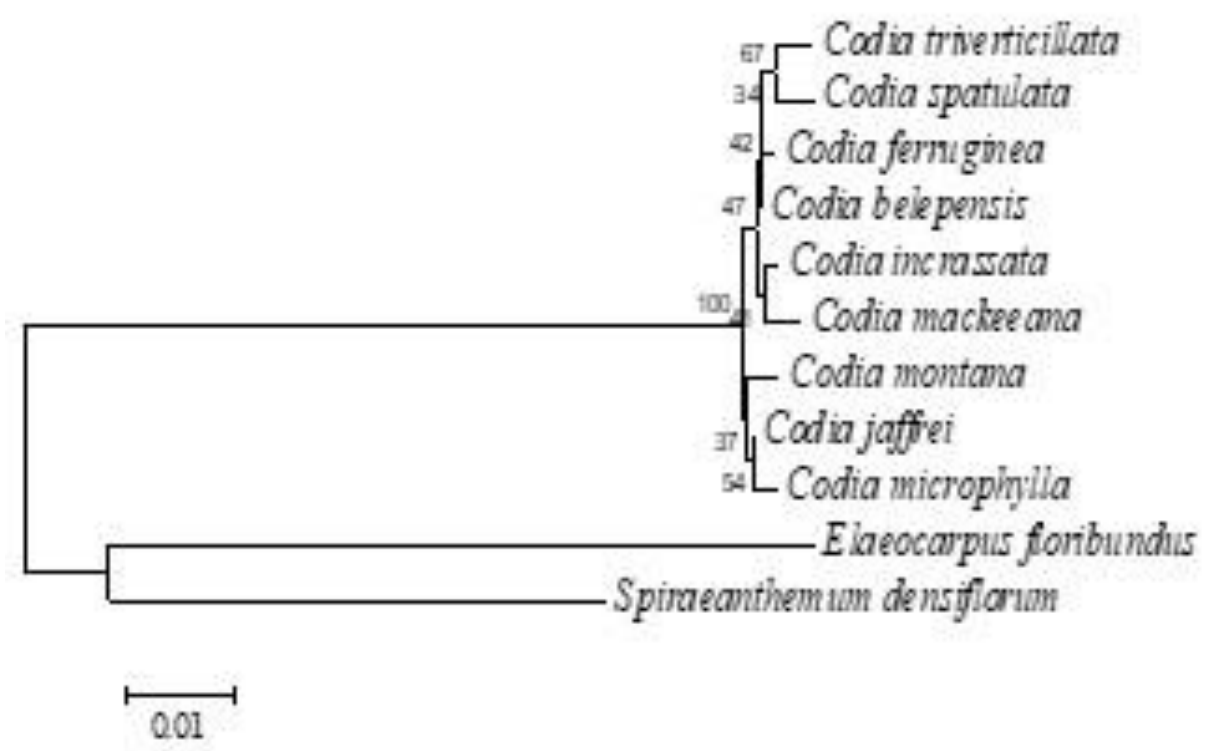

Picture 3. Dendrogram are based on the GapC gene sequence.

The GapC gene obtained in this dactylifera) (Patankar et al., 2016), pigeonpea study further needs to be validated - (Cajanus cajan) (Sinha et al., 2015), citrus one of which is the quantitative real (Mafra et al., 2012) and olive (Olea europaea) time PCR (qRT-PCR) technique - to (Ray \& Johnson, 2014).

determine whether this gene can be Aside from being as an internal control, used as an internal control in $E$. the E. floribundus GapC gene can also function floribundus plants. The GAPDH gene has as a marker of DNA contamination in cDNA been used as an internal control in molecules isolated when gene expression several plants such as dates (Phoenix studies are carried out, because the GapC 
Roslim, D.I., Hairima, H., Herman, and Lestari, W. The DNA Sequence Encoding Glyceraldehyde 3-Phosphate Dehydrogenase (GapC) Enzyme on Elaeocarpus Floribundus BI

gene obtained in this study contains introns and exons. The trick is to amplify the $\operatorname{GapC}$ gene using a template in the form of DNA and cDNA separately. The PCR products with DNA as a template will be $933 \mathrm{bp}$ while cDNA as a template will be $409 \mathrm{bp}$.

\section{CONCLUSION}

The partial GapC gene sequences obtained in this study were $933 \mathrm{bp}$ in size, consisting of 4 introns and 5 exons, and encoded 137 deduction amino acids. BLASTn analysis shows that the sequences obtained in this study have similarities of $89.84 \%-90.16 \%$ and the query cover of $85 \%-90 \%$ with species from the family Cunoniaceae, namely species of the genus Spiraeanthemum and Codia. Sequences of the partial GapC gene of E. floribundus are more similar to sequences in Spiraeanthemum compared to species of the genus Codia. The partial GapC gene sequence of E. floribundus obtained in this study was the first to be reported from the Elaeocarpaceae family.

\section{ACKNOWLEDGMENTS}

Acknowledgments to the Directorate General of Research and Community Service - Directorate
General of Research and Development Ministry of Research, Technology and Higher Education, Republic of Indonesia, which has funded this research through the 2019 Superior Higher Education Basic Research Grant with contract number 756 / UN.19.5. 1.3 / PT.01.03 / 2019.

\section{REFERENCES}

Claverie, J.M. \& Noterdame, C. (2007). Bioinformatics for Dummies, 2nd Editions. Indianapolis, Indiana: Wiley Publishing, Inc.

Elvyra, R. \& Yus, Y. (2012). Ikan Lais dan Sungai Paparan Banjir di Provinsi Riau. Pekanbaru: UR Press Pekanbaru.

Ezin V., Vodounon, C.A., de la Peña, R., Ahanchede, A. \& Handa, A.K. 2012. Gene Expression and Phenotypic Characterization of Flooding Tolerance in Tomato. Journal of Evolutionary Biology Research 4(3): 59-65.

Kozera, B. \& Rapacz, M. (2013). Reference Genes in Real-time PCR. J Appl Genetics 54:391-406.

Mafra, V., Kubo, K.S., Alves-Ferreira, M., RibeiroAlves, M., Stuart, R.M., Boava, L.P., Rodrigues, C.M. \& Machado, M.A. (2012) Reference Genes for Accurate Transcript Normalization in Citrus Genotypes under Different Experimental Conditions. PLoS ONE 7(2): $\mathrm{e} 31263$. doi:10.1371/journal.pone.0031263

Olsen, K.M. \& Schaal, B.A. (1999). Evidence on the Origin of Cassava: Phylogeography of Manihot sculenta. Proc. Natl. Acad. Sci. USA 96: 55865591.

Patankar, H.V., Assaha D.V.M., Al-Yahyai, R., Sunkar, R. \& Yaish, M.W. (2016). Identification of Reference Genes for Quantitative Real-Time PCR in Date Palm (Phoenix dactylifera L.) Subjected to Drought and Salinity. PLoS ONE 11(11): eo166216. doi:10.1371/journal.pone. 0166216.

Ray, D.L. \& Jhonson, J.C. (2014). Validation of reference genes for gene expression analysis in olive (Olea europaea) mesocarp tissue by quantitative real-time RT-PCR. BMC Research Notes.

7:304. 
http://www.biomedcentral.com/17560500/7/304

Roslim, D.I., Azrial, Herman \& Lestari, W. (2018). The GAPDH Partial Gene of Durik-Durik (Syzygium sp.) from Riau Province of Indonesia. IOP Conf. Series: Journal of Physics: Conf. Series. 1116: 052055 .

Roslim, D.I., Khumairoh, S. \& Herman. (2016). Confirmation of Tuntun Angin (Elaeocarpus floribundus) Taxonomic Status Using matK and ITS Sequences. Biosaintifika: J. Biol. Biol. Edu. 8(3): 392399.

Sinha, P., Saxena, R.K., Singh, V.K., Krishnamurthy, L. \& Varshney, R.K. (2015). Selection and validation of housekeeping genes as reference for gene expression studies in pigeonpea (Cajanus cajan) under heat and salt stress conditions. Front. Plant Sci. 6:1071. doi: 10.3389/fpls.2015.01071.
Strand, A.E., Leebens-Mack, J. \& Milligan, B.G. (1997). Nuclear DNA-based markers for plant evolutionary biology. Mol. Ecol. 6, 113-118.

Wang, M-L., Li, Q-H., Xin, H-H., Chen, X., Zhu, X-J., Li X-H. (2017). Reliable Reference Genes for Normalization of Gene Expression Data in Tea Plants (Camellia sinensis) Exposed to Metal Stresses. PLoS ONE 12(4): eo175863. https://doi.org/10.1371/journal.pone.0175863.

Wu, L., Tang, T., Zhou, R. \& Shi, S. (2007). PCRmediated Recombination of The Amplification Products of the Hibiscus tiliaceus Cytosolic Glyceraldehyde-3-phosphate Dehydrogenase Gene. Journal of Biochemistry and Molecular Biology 40(2): 172-179.

Zeng L, Deng R, Guo Z, Yang S, Deng X. 2016. Genome-wide identification and characterization of Glyceraldehyde-3phosphate dehydrogenase genes family in wheat (Triticum aestivum). BMC Genomics 17:240. 